\title{
Bacteria Associated with the Ratoon Stunting Disease of Sugarcane in Puerto Rico'
}

\author{
Lii-Jang Liu, Amelia Cortés-Monllor, Karl Maramorosch, \\ H. Hirumi, J. Enrique Pérez, and Julio Bird²
}

\section{INTRODUCTION}

The ratoon stunting disease of sugarcane has been assumed generally to be caused by a virus. Forbes and Ling in 1960 (4) observed virus particles in affected leaves of sugarcane. They failed to establish the relationship, however, between the observed virus particles and the disease. Gillaspie et al. in 1966 (5) considered the infectious agent of ratoon stunting disease to be a virus. In 1970, Gillaspie (6) reported that ratoon stunting was caused by a virus and not by a mycoplasma. He was unable to obtain remission of symptoms through the use of tetracycline compounds.

On examining sections of ratoon-stunted canes obtained in Puerto Rico with the aid of an electron microscope, Plavsic-Banjac and Maramorosch in 1972 (9) observed the presence of pleomorphic bodies in the xylem but not in the phloem. These bodies resembled small bacteria or mycoplasma. In a recent report by Maramorosch et al. (7), no virus-like particles or microorganisms resembling mycoplasma were observed; the bodies were considered to represent bacteria or rickettsiae.

Concurrently with electron microscope studies at the Boyce Thompson Institute, efforts were being made to isolate microorganisms from ratoon stunted canes in Puerto Rico. Xanthomonas vasculorum-like organisms were isolated from discolored tissues of the xylem vessels of affected canes.

The purpose of this paper is to present the results of studies on the identity and pathogenicity of bacteria isolated from ratoon stunted canes in Puerto Rico.

\section{MATERIALS AND METHODS}

Samples of sugarcane varieties B. 49119, Co. 421, P.R. 980 and P.R. 1059 showing internal symptoms of ratoon stunting were obtained from a ratoon stunting disease yield trial established in 1971 at the Gurabo Substation. Other samples were obtained from Río Piedras and the Lajas areas, but the majority were from Gurabo.

1 Manuscript submitted to Editorial Board March 4, 1974.

2 The first, second, fifth and sixth authors are Phytopathologist, Assistant Bacteriologist, Bacteriologist and Phytopathologist, respectively, Agricultural Experiment Station, Mayagüez Campus, University of Puerto Rico, Rio Piedras, P.R. The third and fourth authors are Virologists from the Boyce Thompson Institute, Yonkers, New York. 
In the isolation studies, Wilbrink's agar (Dowson's 1957 formula) (3) was used. This formula was modified increasing the sucrose to $1.0 \mathrm{~g}$ per $100 \mathrm{cc}$ of the medium. The sucrose solution was previously sterilized through a Seitz filter. Canes affected by ratoon stunting, approximately 6 to 8 months of age, were scrubbed and then washed with tap water. Internodes were cut into 6 -inch long pieces employing sterilized knives. The cut pieces were dipped in 70 percent alcohol for 1 minute and then the surface was flamed with a gas burner. Each of the surface-sterilized pieces was split open and cut into 4 sections under aseptic conditions (Microvoid chamber). Very small pieces of the reddish to orange nodal discolored areas of the vascular bundles were removed and placed on the surface of the abovementioned culture medium. The plates were kept in an incubator at $28^{\circ} \mathrm{C}$.

Yellow growth in mass was observed after 48 to 72 hours of incubation. Agar plates were streaked for determining purity of cultures and all colonies were identical. Gram stain, morphology, motility and general cultural characteristics were used as criteria for identification. Biochemical and serological tests were also made. The standard procedures described in the Manual of Microbiological Methods (2) by the Committee on Bacteriological Technic, Society of American Bacteriologists, were followed for the above-mentioned biochemical tests.

Only some of the more typical $X$. vasculorum-like isolates were subjected to serological tests. In this case, the agglutination test method described by Pérez and Cortés-Monllor (8) for Xanthomonas vesicatoria was followed. The antiserum was prepared against culture 702 of $X$. vasculorum received from the National Collection of Plant Pathogenic Bacteria, Harpenden, Herts., England.

Electron microscopy of these bacteria isolates was conducted at the Boyce Thompson Institute. The bacteria culture was pelleted. The bacteria were fixed in glutaraldehyde. The pellet was embedded in an epoxy resin, sectioned on Sorvall MT-2 microtome with a diamond knife, stained with uranyl acetate and lead citrate and observed in a Siemens Elmiskop 1 at $80 \mathrm{KV}$.

Healthy seedpieces, derived from hot water treated B. 49119 cane, were used in the pathogenicity trials. Six- to eight-day cultures grown on Wilbrink's agar were used as inoculum. Bacterial suspensions were prepared in distilled water. Seedpieces of sugarcane were cut while submerged in the bacterial suspension, and retained in the suspension for 5 minutes, and then planted. Two controls, one consisting of uninoculated, hot water treated plants, and another consisting of ratoon stunt affected canes, were included. Two months after inoculation, canes arising from the seedpieces were split open with a sterilized knife and examined for symptoms of ratoon stunting disease. 
In the filtration studies, juice expressed from ratoon stunted canes was divided into two equal parts. One part was filtered through a steam sterilized Seitz filter assembly and the filtrate used directly to inoculate healthy seedpieces of sugarcane, derived from a hot water treated nursery. The unfiltered fraction was used as control.

\section{RESULTS}

As shown in table 1, Xanthomonas vasculorum-like organisms were isolated from ratoon stunt affected sugarcane plants of varieties B. 49119, Co. 421, and P.R. 980. Approximately 30 percent of the isolates were $X$.

TABLE 1.-Isolation of Xanthomonas vasculorum-like organisms from canes
affected by ratoon stunting disease

vasculorum-like. The rest were presumably saprophytes or contaminants forming large dark yellow colonies.

\section{IDENTIFICATION}

\section{A. Morphology}

$X$. vasculorum-like organisms were gram negative, approximately $0.4-0.5$ $\mu \mathrm{m}$ in width $\times 1.0-1.5 \mu \mathrm{m}$ in length and motile (as observed in a motility medium and hanging drop preparations). Colonies were light-yellow, 0.5 to $1 \mathrm{~mm}$ in diameter (2 to 3 days old culture), buttery, smooth and shiny.

\section{B. Biochemical Tests}

The results obtained from biochemical tests indicated that isolates R-2-6, R-3A and R-9J were probably $X$. vasculorum. As shown in table 2, isolates 
TABLE 2.-Biochemical reactions of some bacterial isolales from ratoon slunted canes

\begin{tabular}{|c|c|c|c|c|c|c|c|}
\hline Test & R-2-6 & $R-3 A$ & R-5 & R-6 & $R=7$ & R-S & R-9J \\
\hline 1. Hydrolysis of starch & + & + & - & - & - & - & - \\
\hline $\begin{array}{l}\text { 2. Liquefaction of yeast } \\
\text { pectate }\end{array}$ & + & - & - & - & - & - & - \\
\hline 3. Liquefaction of gelatin & + & + & + & + & + & + & + \\
\hline 4. Lipolysis & + & + & - & - & - & - & - \\
\hline 5. $\mathrm{H}_{2} \mathrm{~S}$ & + & + & + & + & - & - & + \\
\hline 6. Indole & - & - & - & - & - & - & - \\
\hline $\begin{array}{l}\text { 7. M.R. test (Methyl-red } \\
\text { test) }\end{array}$ & - & + & - & - & - & - & - \\
\hline $\begin{array}{l}\text { 8. V.P. test (Voges-Pros- } \\
\text { kaver reaction) }\end{array}$ & - & - & + & - & + & - & - \\
\hline 9. Nitrite from nitrate & - & - & + & - & - & - & - \\
\hline 10. Citrate utilization & + & + & + & + & + & - & + \\
\hline 11. Malonate utilization & - & + & + & + & - & - & - \\
\hline 12. Urease & $\stackrel{+}{+}$ & $\stackrel{+}{+}$ & - & $\stackrel{+}{+}$ & - & - & $\stackrel{+}{+}$ \\
\hline $\begin{array}{l}\text { 13. Salt tolerance } 5 \text { and } 7 \text { per- } \\
\text { cent }\end{array}$ & - & - & + & - & + & - & - \\
\hline 14. Action on litmus milk & $\operatorname{cda} \mathbf{a}^{2}$ & $\operatorname{cda}$ & cda & cda & $\operatorname{cca} a^{2}$ & cda & cda \\
\hline 15. Aesculin hydrolysis & + & $\mathbf{x}$ & $x$ & $\mathrm{x}$ & $\mathrm{x}$ & + & + \\
\hline $\begin{array}{l}\text { 16. Catalase test } \\
\text { 17. Action on carbohydrates: }\end{array}$ & - & $\mathbf{x}$ & $\mathrm{x}$ & $\mathrm{x}$ & $\mathrm{x}$ & - & + \\
\hline Lactose & + & + & - & + & + & - & + \\
\hline Glucose & + & + & - & + & + & + & + \\
\hline Sucrose & + & + & - & + & + & - & + \\
\hline Maltose & + & + & - & + & + & - & + \\
\hline Arabinose & + & + & - & + & + & + & + \\
\hline Levulose & + & + & - & + & + & + & + \\
\hline Mannose & + & + & - & + & + & + & + \\
\hline Mannite & + & - & - & + & + & - & + \\
\hline Xylose & + & - & - & + & + & + & + \\
\hline Salicin & - & + & - & + & - & - & - \\
\hline Dulcitol & - & - & - & + & - & - & - \\
\hline Raffinose & - & + & - & + & + & - & - \\
\hline
\end{tabular}

Note: All reactions observed for 28 days. +; Change in $\mathrm{pH}$ to the acid side. - ; No change in $\mathrm{pH}$ to the acid side. $\mathrm{x}$; Test not included.

1 cda $=$ casein digested and alkaline.

${ }^{2}$ cea $=$ casein coagulated and acid.

R-2-6 and R-9J possess characteristics typical of $X$. vasculorum, namely, 1, liquefaction of gelatin; 2 , digestion of milk; 3 , no reduction of nitrates; 4 , no formation of indole; 5 , hydrolysis of starch; and 6, no action on salicin. Isolate $R-3 A$ gave positive reaction on salicin.

Two isolates (one with the most typical and another with the least typical characteristics of $X$. vasculorum) wre sent August 22.2, 1972 to Dr. MI. 
B. Ellis, Principal Pathologist, Commonwealth Mycological Institute, Kew, Surrey, England for identification. Dr. C. Booth (1), Assistant Director of the Institute, reported the findings as follows: 1, R-2-6 (IMI B. 5289) has been identified as $X$. sp., probably $X$. vasculorum (Cobb) Dowson; 2, R-3A (IMI B. 5290) has been identified as Flavobacterium sp., not a plant pathogen.

\section{Serological Tests}

As shown in table 3, isolates R-2-6, R-8, and R-9J gave a positive reaction in the agglutination test for $X$. vasculorum, although some of the isolates reacted positively (agglutination test) with a low dilution of serum.

TanLe 3.-Agglutination reactions for Xanthomonas vasculorum by baclerial isolates from ratoon stunting diseased canes

\begin{tabular}{lcc}
\hline \multicolumn{1}{c}{ Isolates } & $\begin{array}{c}\text { Antiscrum for } X_{\text {. iescrlorum }} \\
\text { cultures (titers) }\end{array}$ & Normal serum \\
\hline R-2-6 & $+1 / 1,280$ & -1 \\
R-3A P.R. 980 & $+1 / 160$ & - \\
R-3B Co. 421 & - & - \\
R-3C P.R. 62-258 & - & - \\
R-5 & - & - \\
R-6 & - & - \\
R-7 & - & - \\
R-8 & $+1 / 640$ & - \\
R-9J & $+1 / 1,560$ & - \\
\hline
\end{tabular}

1 The dash signs indicate a negative reaction at the lowest dilution of serum tested $(1 / 10)$.

\section{Electron Microscopy}

The results obtained from electron microscopy studies indicated that there appeared to be some morphological resemblance between one of the bacterial isolates, Xanthomonas sp. (fig. 1), and the xylem invaders described previously by Maramorosch et al. (7).

\section{PATHOGENICITY}

As shown in table 4, isolate R-2-6 produced symptoms of ratoon stunting in three of the five inoculated seedpieces. The rest of the isolates failed to produce either symptoms of gumming disease or those of ratoon stunting disease. None of the canes inoculated with filtered juice (filtrate) from ratoon stunted plants produced symptoms of the disease, while canes inoculated with the unfiltered juice did so. 


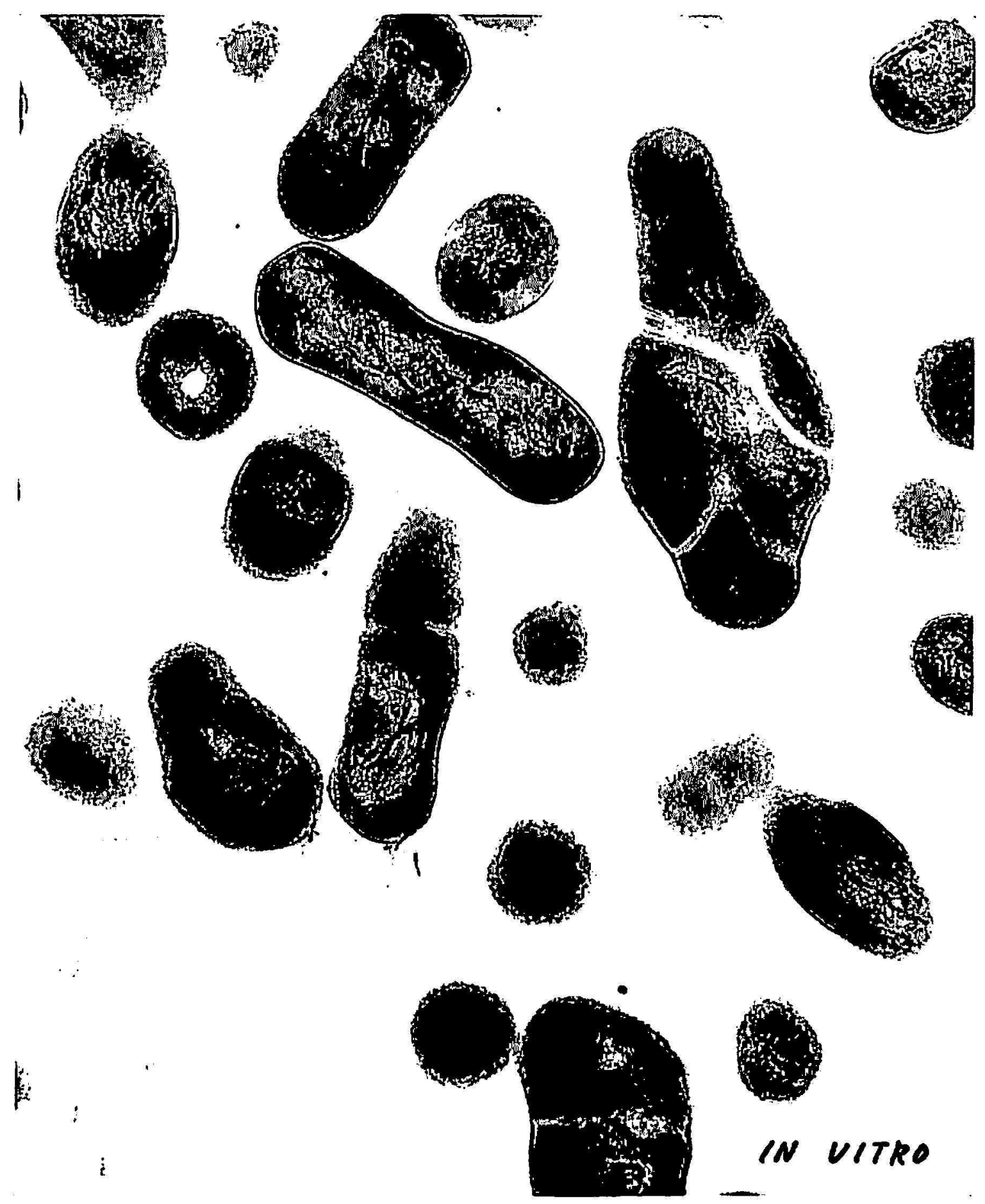

FIg. 1.-Thin section of cultured Xanlhomonas vasculorum cells, isolated from sugarcane ratoon stunted material. The procaryotic structure of the microorganisms is illustrated by the typical layered cell wall and a cytoplasm containing a dispersed nucleus and ribosomes. Note dividing cells $(\times 36,000)$.

\section{DISCUSSION}

The results obtained in this study agree in general with the findings of Maramorosch et al. (7), who reported the presence of bacteria or perhaps rickettsiae in the vascular bundles of canes affected by ratoon stunting 
disease. The bacteria have been identified now as belonging to the Xanthomonas vasculorum group. It is of interest to note that the filtrate obtained by passing infective juices through a Seitz bacterial filter failed to incite symptoms on healthy canes, in direct contrast with the results obtained with the unfiltered juice. According to Booth (1), all members of the order Rickettsiales are obligate animal parasites and can te cultivated outside the animal host only in living tissues. Presumably they would not be present in a bacterial culture on an artificial medium. Perhaps, if rickettsiae had been present in the juice expressed from ratoon stunting diseased canes, they would have passed through the bacterial filter. This last would have been evidenced by the appearance of symptoms on canes inoculated with the filtrate.

TABLE 4.-Effect of inoculation wilh bacteria and juice from raloon slunled canes on development of symploms by plants of variely B. 49119

\begin{tabular}{ccc}
\hline Treatment & Age of culture & $\begin{array}{c}\text { Number of plants infected/ } \\
\text { number of plants inoculated }\end{array}$ \\
\hline Bacterial isolates & & \\
R-2-6 & 6 days & $3 / 5$ \\
R-3B & 6 days & $0 / 8$ \\
R-5 & 6 days & $0 / 9$ \\
R-8 & 6 days & - \\
R-9J & 8 days & $0 / 20$ \\
Cane juice & & $0 / 30$ \\
Filtered & & $20 / 30$ \\
Non-filtered & & \\
\hline
\end{tabular}

Evidence obtained in these studies indicates that bacterial organisms, presumably of the $X$. vasculorum group, are responsible for the ratoon stunting discase of sugarcane. The results of these researches substantiate the evidence obtained by Maramorosch et al. (7) by electron microscopy. They also are in line with recent findings obtained in Australia by Teakle et al., who consistently isolated a bacterium from the sap of sugarcane ratoon stunted material (11).

\section{SUMMARY}

Xanthomonas vasculorum-like organisms were isolated from xylcm vessels in the nodal regions of sugarcane plants of varieties B. 49119, Co. 421, and P.R. 980 affected by ratoon stunting disease. The isolates were identified via biochemical and serological tests probably as $X$. vasculorum. One of the isolates produced symptoms closely resembling those associated with the ratoon stunting disease. Healthy plants inoculated with juice expressed 
from ratoon stunted canes, and passed through a Seitz bacterial filter, failed to develop symptoms of the disease.

\section{RESUMEN}

Bacterias parecidas a Xanthomonas vasculorum se aislaron de los haces vasculares de tallos de caña de las variedades B. 49119, Co. 421 y P.R. 980 afectadas por el enanismo del retoño. Las pruebas bioquímicas y serológicas que se hicieron indican que probablemente se trata de $X$. vasculorum. Uno de los cultivos reveló síntomas muy parecidos a los que normalmente se asocian con el enanismo. No se logró reproducir los síntomas de la enfermedad al inocularse cañas sanas con el jugo de cañas afectadas, después de pasarse por un filtro bacteriológico del tipo Seitz:

\section{LITERATURE CITED}

1. Booth, C., Personal communication, September 27, 1972.

2. Committee on Bacteriological Technic, Society of American Bacteriologists, Manual of Microbiological Methods, 315 pp. McGraw Hill Book Co., Inc., New York, N.Y., 1957.

3. Dowson, W. J., Plant diseases due to bacteria, 2nd ed., Cambridge University Press.

4. Forbes, I. L., and Ling, K. C., Particles associated with the ratoon stunting of sugarcane, Sugar J. 23: 2, 1960.

5. Gillaspie, A. G., Irvine, J. E., and Steere, R. L., Ratoon stunting disease virus, assay technique and partial purification, Phytopathology 56: 1,426-7, 1966.

6. - Evidence that ratoon stunting disease of sugarcane is caused by virus and not mycoplasma, Phytopathology 60(10): 1,448-50, 1970.

7. Maramorosch, K., Plavsic-Banjac, B., Bird, J., and Liu, L. J., Electron microscopy of ratoon stunted sugarcane microoragnisms in xylem, Phytopathologische Zeitschrift 77 : 270-3, 1973.

8. Pérez, J. E., and Cortés-Monllor, A., Xanthomonas vesicatoria in Puerto Rico, J. Agr. Univ. P.R. 45(4) : 304-10, 1961.

9. Plavsic-Banjac, B., and Maramorosch, K., Electron microscopy of the xylem of ratoon stunted sugarcane, Phytopathology $62(5): 498,1972$.

10. Steib, R. J., and Tantera, D. M., Studies to determine effect of tetracycline antibiotic on ratoon stunting disease, Sugar Bull. 32, 217-9, 1970.

11. Teakle, D. S., Smith, Paula M., and Steindl, D. R. L., Association of a small coryneform bacterium with the ratoon stunting disease of sugarcane, Australian J. Agr. Res. 24(6): 869-74, 1974. 